\title{
Analisis Pola Migrasi Penduduk di Dataran Tinggi Kabupaten Aceh Tengah Provinsi Aceh (Dimensi Sosial, Ekonomi, dan Infrastruktur)
}

\author{
Muhammad Zulhilmi \\ Program Studi Ekonomi Syariah FEBI UIN Ar-Raniry \\ e-mail:rmuha.zul@gmail.com \\ Hafiizh Maulana \\ Program Studi Ekonomi Syariah FEBI UIN Ar-Raniry \\ e-mail: hafiizh.maulana2@gmail.com
}

\begin{abstract}
Abstrak
Kebijakan pengendalian jumlah penduduk di Kabupaten Aceh Tengah dihadapkan pada persoalan penurunan kualitas penduduk dengan tingginya jumlah imigran yang masuk. Penelitian ini ingin menjawab serangkaian permasalah migrasi dengan menelaah secara mendalam pola migrasi penduduk dan faktor-faktor yang mempengaruhinya. Penelitian dilakukan pada 14 kecamatan di Kabupaten Aceh Tengah, dengan model estimasi migrasi data cross section. Model migrasi yang dihasilkan membagi model dalam lingkup sosial, ekonomi/ketenagakerjaan, dan infrastruktur. Pola migrasi risen yang masuk di Kabupaten Aceh Tengah secara sosial dipengaruhi oleh faktor pendidikan, beban ketergantungan yang tinggi, fasilitas kesehatan. Sementara dalam lingkup ekonomi, tingkat partisipasi angkatan kerja dan jumlah penduduk bekerja menambah tingginya migrasi risen yang masuk. Dalam lingkup infrastruktur penduduk akan bergerak secara masif terjadi karena faktor akses perumahan dan sumber penerangan listrik. Pemerintah Kabupaten Aceh Tengah diharapkan dapat responsif dalam membuat perencanaan pembangunan yang berbasis kependudukan dengan memperhatikan faktor migrasi penduduk di daerah tersebut.
\end{abstract}

Kata kunci: Migrasi, sosial, ekonomi, infrastruktur.

\section{PENDAHULUAN}

Kebijakan terkait pengendalian jumlah penduduk diarahkan pada upaya pemerataan distribusi penduduk melalui program migrasi. Pada kenyataannya, program migrasi yang masuk dari suatu daerah ke daerah lain menimbulkan masalah penurunan kualitas penduduk di daerah tujuan. Hal ini karena program migrasi seperti memindahkan masalah penduduk di daerah asal ke daerah tujuan. Berdasarkan agenda dari program pembangunan Nawacita 2015-2019 yang digariskan di dalam pemerintah Jokowi-JK, agenda prioritas ke-3 berhubungan dengan membangunkan Indonesia dari pinggiran dengan memperkuat daerah-daerah serta desa dalam rangka memelihara negara kesatuan.
Adanya magnet pembangunan yang terpusat pada wilayah-wilayah perkotaan, mendorong pergerakan penduduk menuju kota sehingga penduduk kota semakin padat.

Sekitar $12 \%$ dari 237 juta jiwa penduduk Indonesia tinggal di provinsi yang berbeda dengan provinsi tempat lahirnya (BPS, 2015). Hal ini membuktikan bahwa perpindahan penduduk (migrasi) menjadi bagian penting dalam kehidupan masyarakat Indonesia dan dunia. Todaro (1998) menyatakan bahwa migrasi merupakan suatu proses yang sangat selektif mempengaruhi setiap individu dengan ciri-ciri ekonomi, sosial, pendidikan dan demografi tertentu maka pengaruhnya terhadap faktor-faktor 
ekonomi dan non ekonomi dari masingmasing individu juga bervariasi.

Badan Kependudukan dan Keluarga Berencana Nasional (BKKBN) yang di amanat dalam pengendalian jumlah penduduk berdasarkan Undang-undang Nomor 52 Tahun 2009 terus berupaya meningkatkan kualitas manusia Indonesia. Perwujudan dari upaya pengendalian penduduk tersebut salah satunya adalah dilakukan melalui implementasi program Kependudukan, Keluarga Berencana dan Pembangunan Keluarga (KKBPK). Hal utama yang harus dilakukan untuk mewujudkan program KKBPK ini adalah estimasi yang tepat dalam distribusi penduduk daerah secara merata dengan mempertimbangkan aspek-aspek ekonomi, sosial-budaya dan infrastruktur.

Salah satu perubahan mendasar dari pola migrasi penduduk dipengaruhi oleh situasi ekonomi yang memicu tingginya mobilitas penduduk. Adanya kebijakan untuk mengejar pertumbuhan ekonomi, memunculkan trade-off bagi daerah-daerah kutub pertumbuhan ekonomi yang dihadapkan pada mobiltas penduduk tinggi tinggi. Kebijakan infraksturtur yang mendorong konektiftas antar pulau, di sisi yang lain harus didukung juga oleh kebijakan kependudukan.

Kabupaten Aceh Tengah menjadi salah satu daerah tujuan migrasi yang tinggi dalam perhitungan migrasi seumur hidup tahun 2015. Migrasi risen Aceh Tengah melingkupi $75 \%$ dari total penduduk yang ada di Aceh Tengah (Sensus Penduduk, 2015). Namun demikian, hal yang paradoks terjadi dimana angka migrasi masuk yang tinggi tidak diikuti dengan kualitas hidup manusia yang juga tinggi. Berikut ini Indeks Pembangunan Manusia (IPM) Kabupaten Aceh Tengah.

Data ini menujukkan bahwa migrasi yang masuk di wilayah tertinggal Kabupaten Aceh Tengah tidak diimbangi dengan penguatan sisi kualitas hidup manusia. Apabila merujuk pada data IPM selama tahun 20112016, pertumbuhan IPM Aceh tengah masih mengalami ketertinggalan dengan pertumbuhan IPM Provinsi Aceh. Penurunan yang terjadi masih berlangsung pada pada tahun 2016 sebesar 0,4\%. (dihimpun dari data kependudukan BPS Provinsi Aceh, 2016). Keadaan ini sekiranya menunjukkan adanya kekhawatiran terjadinya penurunan kualitas hidup manusia.

Model estimasi migrasi penduduk Aceh Tengah perlu dilakukan dalam spektrum tingkat kecamatan yang melibatkan varibelvariabel ekonomi, sosial, dan infrakstrukur publik. Secara spesifik, analisis ini akan melihat migrasi risen yang terjadi di Kabupaten Aceh Tengah. Migrasi risen digunakan sebagai salah satu indikator untuk melihat pergerakan penduduk yang masuk di Kabupaten Aceh Tengah.

Penelitian model estimasi migrasi penduduk Indonesia, berangkat dari masalah kualitas pembangunan manusia yang rendah Kabupaten Aceh Tengah. Migrasi yang masuk dan keluar dengan tanpa adanya perencanaan yang matang bisa menghambat program pemberdayaan ekonomi masyarakat di wilayah tertinggal. Untuk itu, rumusan masalah yang ingin ditelaah dalam penelitian ini adalah bagaimana pola migrasi penduduk ditinjau dari aspek ekonomi, sosial, dan infrastruktur di Kabupaten Aceh Tengah.

\section{Migrasi}

Migrasi adalah perpindahan penduduk dengan tujuan untuk menetap dari suatu tempat ke tempat lain melampaui batas politik/negara atau batas administratif/batas bagian dalam suatu negara (Munir, 2011).

Menurut BPS (2015), migrasi dalam arti luas adalah perubahan tempat tinggal secara permanen tidak ada pembatasan baik pada jarak perpindahan maupun sifatnya yaitu apakah tindakan itu bersifat sukarela atau terpaksa, serta tidak ada perbedaan antar perpindahan di dalam negeri dan atau ke luar negeri. Migrasi dalam SP 2010 adalah perpindahan penduduk dengan memiliki tujuan menetap dari suatu tempat ke tempat lain melewati batas administratif provinsi (migrasi internal). 


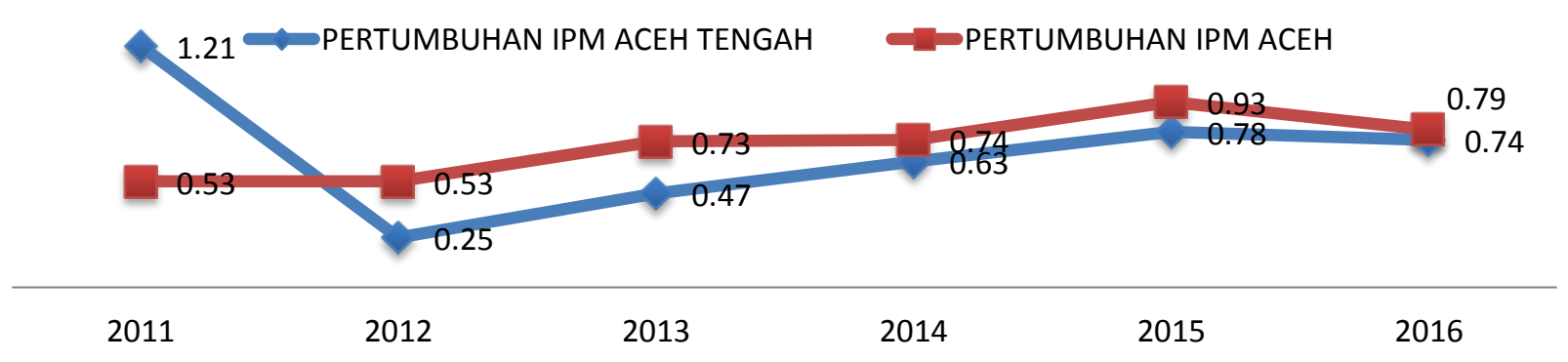

Sumber: Data BPS Kabupaten Aceh Tengah (diolah), Tahun 2017.

\section{Gambar 1.Grafik IPM dan ABK Aceh Singkil dan Provinsi Aceh Periode 2011-2016}

Migrasi dinyatakan sebagai proses perpindahan penduduk dari suatu wilayah ke wilayah lainnya, yang diikuti perubahan kehidupan sosial, ekonomi, serta budaya masyarakat. Todaro (1998) berpendapat bahwa migrasi merupakan suatu proses yang sangat selektif mempengaruhi setiap individu dengan ciri-ciri ekonomi, sosial, pendidikan dan demografi tertentu, maka pengaruhnya terhadap faktor-faktor ekonomi dan non ekonomi dari masing-masing individu juga bervariasi.

Batasan waktu migran ditetapkan enam bulan sejalan dengan konsep tempat tinggal, artinya seorang dikatakan migran jika tinggal ditempat baru atau berniat tinggal di tempat baru paling sedikit enam bulan lamanya. Keterangan bahwa seseorang pernah pindah atau tidak bisa dilihat pada ada tidaknya perubahan tempat tinggal. Perbedaan tempat tinggal inilah yang digunakan sebagai proksi migrasi.

Beberapa teori migrasi menyatakan bahwa faktor ekonomi merupakan salah satu faktor penting yang mempengaruhi terjadinya perpindahan penduduk, seperti perbedaan dalam kesempatan memperoleh pendapatan dan lingkungan kehidupan yang layak; ketimpangan ekonomi yang terjadi antara satu daerah dengan daerah lainnya. Faktor jarak antara daerah asal dengan daerah tujuan, yang disebut sebagai rintangan antara, juga sangat menentukan keputusan seseorang untuk berpindah (Munir, 2011). Banyak migran di Indonesia menuju wilayah yang berjarak dekat, sedangkan migran yang jauh tertuju kepada pusat-pusat perdagangan dan industri, (Emalisa, 2003). Sementara itu, Lee (1966) menyebutkan bahwa faktor daerah asal dan tujuan menjadi alasan bagi seseorang dalam mengambil keputusan untuk melakukan migrasi.

Ditinjau dari sudut pandang ekonomi, berbagai teori migrasi telah dikembangkan dalam menganalisa mobilitas penduduk.Teoriteori tersebut terus berkembang seiring dengan perkembangan tingkat sosial-ekonomi masyarakat dan penelitian yang terus menerus dilakukan. Penelitian ilmiah tentang migrasi pertama kali diperkenalkan oleh Ravenstein, dimana dia merumuskan "The Laws of Migration". Ravenstein berpendapat bahwa migrasi merupakan hal yang tidak dapat dipisahkan dari pembangunan dan dorongan utama migrasi adalah motif ekonomi (Lee, 1966).

Pola migrasi berikutnya adalah pandangan Skeldon (1997) yang berasumsi bahwa gerakan perpindahan cenderung ke arah keseimbangan spasial-ekonomi tertentu. Tjiptoherijanto (2000) mengungkap terjadinya mobilitas dan perpindahan penduduk yang terjadi di Indonesia didorong oleh kegiatan pembangunan ekonomi. Proses pembangunan ekonomi tidak hanya terkait dengan sebaran sumber daya yang ada, tapi juga terkait dengan kebijakan pemerintah di dalam mengalokasikan sumber daya. Selain faktor ekonomi, migrasi juga turut dipengaruhi oleh faktor-faktor non ekonomi seperti psikologi dan demografi. Teori pengambilan keputusan untuk bermigrasi di tingkat individu dari perspektif geografi yang berpengaruh kuat dalam analisis-analisis migrasi pada era 1970an hingga menjelang awal tahun 1990-an. Menurut Lee (dalam Wirawan, 2006), 
keputusan bermigrasi di tingkat individu, dipengaruhi oleh empat faktor. Faktor pertama adalah faktor-faktor yang ada di daerah asal migran; faktor kedua adalah faktor yang terdapat di daerah tujuan migrasi; ketiga adalah faktor penghalang migrasi; dan, faktor terkhir adalah factor individu pelaku migrasi (pribadi).

Faturochman (2002) dalam tulisannya menyebutkan bahwa migran sebagai agen memiliki peran yang dominan dalam model prokologi pengambilan keputusan untuk migrasi. Model ini menyatakan bahwa berbagai perhitungan dilakukan sehingga orang mengambil keputusan berangkat atau tidak. Dengan beberapa langkah-langkah antara lain penimbangan terhadap tantangan, mencari dan memilih alternatif, hingga mengdeklarasikan komitmen sebagai wujud keputusan. Langkah itu merupakan analisis yang cukup sederhana sedangkan banyak orang juga tidak dapat memutuskan sesuatu dengan cepat dan cermat dikarenakan sulitnya mengidentifikasi motivasi atau kurang kuatnya motivasi. Hal tersebut menyebabkan migran sebagai agen tidak cukup besar peranannya.

Kajian mengenai proses migrasi internasional salah satunya ditulis oleh Rogler (1994) yang dipublikasikan dalam buletin American Psychologist (Faturochman, 2002) yang mengkaji mengenai kerangka migrasi dari pendekatan psikologis. Menurut Rogler (1994), migrasi internasional dapat dilihat dari konteks utama, yaitu konteks daerah asal dan konteks daerah tujuan. Kedua konteks tersebut bertemu dan tampak dalam karakteristik migran. Sebagai contoh, migran dari wilayah $\mathrm{X}$ dengan karakteristik $\mathrm{A}$, cenderung akan bermigrasi ke wilayah Y. Fenomena ini sering dijelaskan dalam proses migrasi berupa penjelasan faktor-faktor ekonomi, sebagai push dan pull factors, serta aspek kultural dari kedua wilayah. Keterkaitan lintas atau antar budaya dalam proses migrasi menjadi bagian yang penting. Arus migrasi bukan kejadian yang acak.

Berdasarkan telaah masalah serta tinjauan teoritis yang dilakukan, estimasi model migrasi ditunjukkan pada Gambar 2.

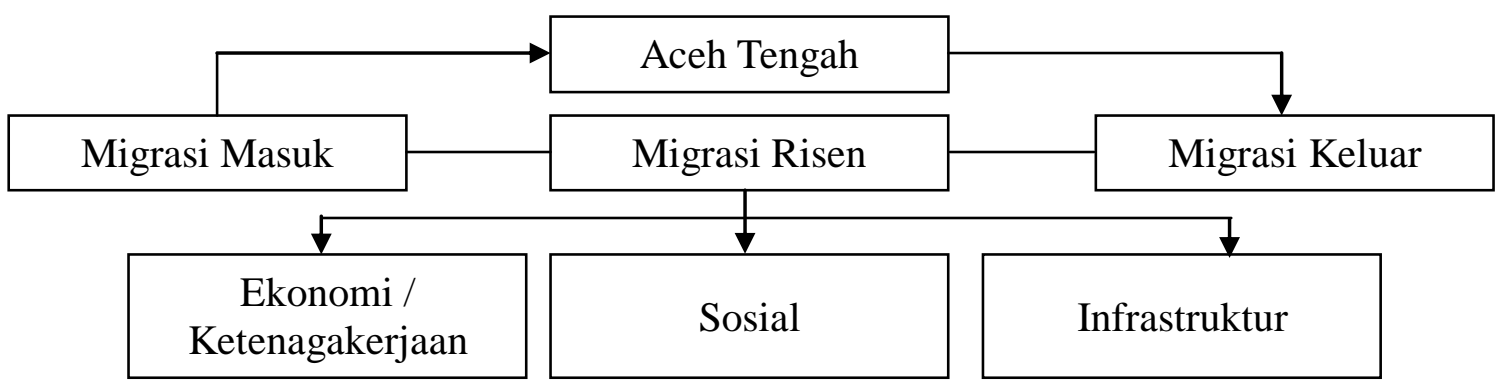

Sumber: Diolah Peneliti, Tahun 2017.

\section{Gambar 2. Kerangka Pikir Penelitian}

\section{METODE PENELITIAN}

Metode penelitian ini didesain dengan menggunakan pendekatan metode kuantitatif. Penelitian ini dilakukan dengan menggunakan data sekunder yang diambil dari raw data Sensus Penduduk dan Survey Penduduk Antar Sensus (SUPAS) masing-masing tahun 2010. Untuk data pendukung ditinjau juga publikasi dari BPS berkaitan dengan data ketenagakerjaan, sosial, dan infrastruktur. Lokasi penelitian terdiri dari 14 kecamatan yang terdiri dari Kecamatan Linge, Atu Lintang,
Jagong, Jeget, Bintang, Laut Tawar, Kebayakan, Pegasing, Bies, Bebesan, Kute Panang, Silih Nora, Ketol, Kelala, Celala, dan Rusip Antara.

Penelitian migrasi ini dilakukan pada wilayah tertinggal Kabupaten Aceh Singkil. Teknik analisis yang dilakukan menggunalan estimasi model regresi linear berganda cross section. Metode analisis dalam penelitian terdiri dari beberapa tahapan, yaitu: 


\section{Model Sosial.}

$$
\begin{aligned}
M R_{\mathrm{i}}= & \beta_{0}+\beta_{1} B K_{\mathrm{i}}+\beta_{2} \text { Faskes }_{\mathrm{i}} \\
& +\beta_{3} \text { Educ }_{\mathrm{i}}+\varepsilon_{\mathrm{i}}
\end{aligned}
$$

dimana $\beta_{0}$ adalah Konstanta (intercept); $\beta_{1}$ sampai $\beta_{3}$ adalah Slope; $M R$ adalah migrasi risen; $B K$ adalah beban ketergantungan; Faskes adalah fasilitas kesehatan; Educ adalah jumlah penduduk yang tidak sekolah; $\varepsilon$ adalah error; dan $i$ adalah banyaknya data cross section (yaitu: 14 kecamatan).

\section{Model Ekonomi/Ketenagakerjaan.}

$$
\begin{aligned}
M R_{\mathrm{i}}= & \beta_{0}+\beta_{1} T P A K_{\mathrm{i}}+\beta_{2} B_{i}+\beta_{3} K_{\mathrm{i}} \\
& +\beta_{4} P B B_{\mathrm{i}}+\varepsilon_{\mathrm{i}}
\end{aligned}
$$

dimana $\beta_{0}$ adalah Konstanta (intercept); $\beta_{1}$ sampai $\beta_{4}$ adalah Slope; $M R$ adalah migrasi risen; TPAK adalah tingkat partisipasi angkatan kerja; $B$ adalah rasio penduduk bekerja terhadap total penduduk; $K$ adalah tingkat kepadatan; $P B B$ adalah persentase pajak bumi dan bangunan; $\varepsilon$ adalah error; dan $i$ adalah banyaknya data cross section (yaitu: 14 kecamatan).

\section{Model Infrastruktur.}

$$
M R_{\mathrm{i}}=\beta_{0}+\beta_{1} L_{\mathrm{i}}+\beta_{2} P_{i}+\beta_{3} K_{\mathrm{i}}+\varepsilon_{\mathrm{i}}
$$

dimana $\beta_{0}$ adalah Konstanta (intercept); $\beta_{1}$ sampai $\beta_{3}$ adalah Slope; $M R$ adalah migrasi risen; $L$ adalah sumber penerangan listrik; $P$ adalah akses memiliki rumah; $K$ adalah akses komunikasi; $\varepsilon$ adalah error; dan $i$ adalah banyaknya data cross section (yaitu: 14 kecamatan).

\section{HASIL ANALISIS}

Secara umum, Migrasi di wilayah Kabupaten Aceh Tengah ditelaah pada lingkup kecamatan yang berjumlah 14 kecatamatan. Migrasi menjadi salah satu problem yang menunjukkan banyak arus masuk penduduk dari luar selama periode waktu 10 tahun. Pada Gambar 3 ditampilkan angka migrasi seumur hidup dan migrasi risen berdasarkan sensus penduduk tahun 2010 .

Berdasarkan grafik pergerakan jumlah arus masuk penduduk (Gambar 3), total migrasi seumur hidup penduduk Kabupaten Aceh Tengah adalah 169.398 jiwa. Jumlah ini, dibandingkan total penduduk Kabupaten Aceh Tengah tahun 2016 sebanyak 200.412 jiwa (Aceh Tengah dalam Angka, 2017), maka penduduk berstatus imgran melingkupi $85 \%$ dari total penduduk Kabupaten Aceh Tengah. Atau, penduduk di Aceh Tengah banyak didiami imigran dari luar Kabupaten tersebut.

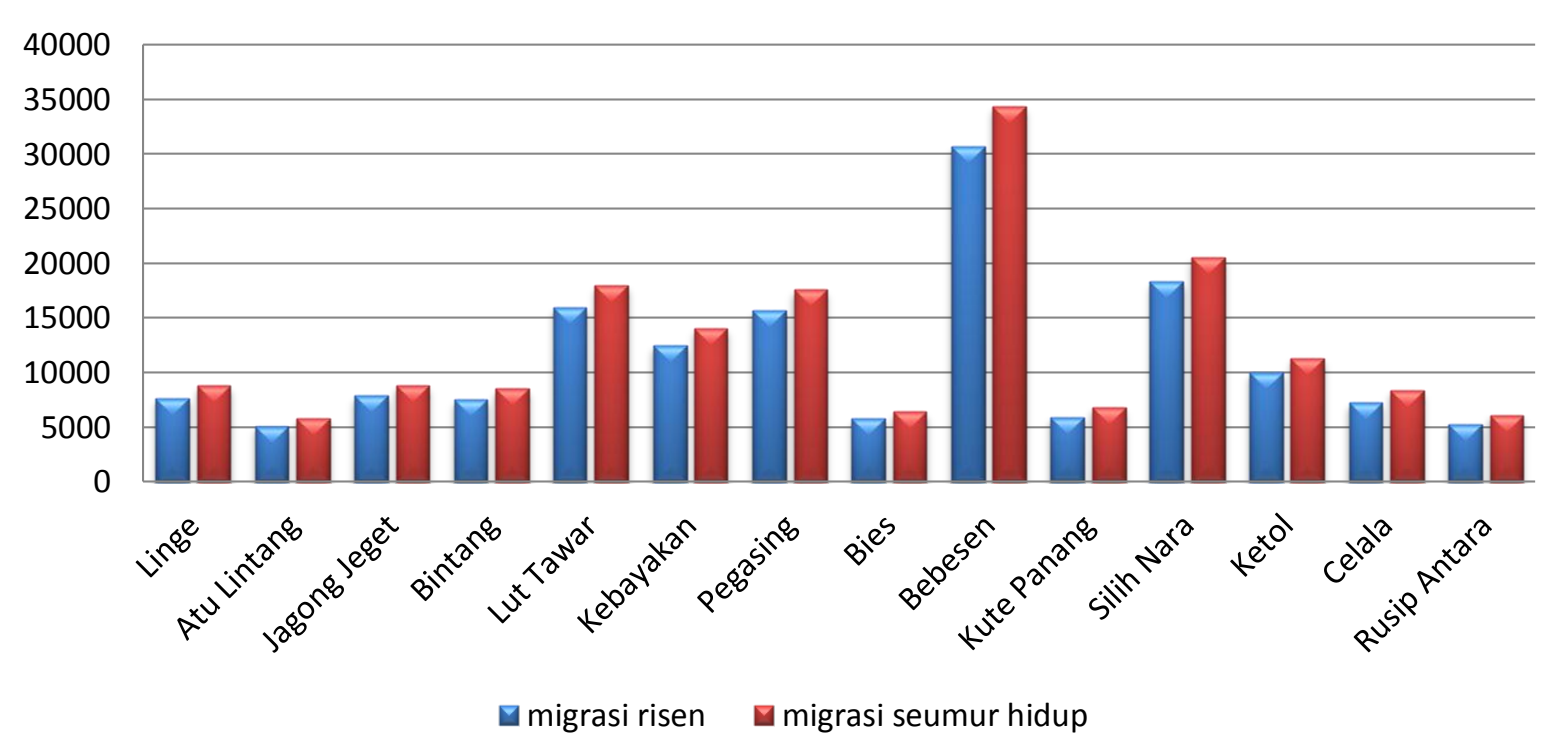

Sumber: Data Sensus Penduduk Tahun 2010 (diolah), Tahun 2017.

Gambar 3. Migrasi Risen dan Seumur Hidup Kabupaten Aceh Tengah Tahun 2010 
Data perbandingan lainnya adalah tingkat migrasi risen yang memperhitungkan pergerakan penduduk kabupaten Aceh tengah dalam lima tahun terakhir. Jumlah ini secara akumulatif sebanyak 150.136 jiwa. Maka jika dibandingkan dengan total penduduk Aceh Tengah, jumlah imigran dalam lima tahun terakhir melingkupi $75 \%$ dari total jumlah penduduk.

Konsentrasi penduduk terpusat dalam jumlah yang besar di Kecamatan Bebesen sebanyak adalah 30.624 Jiwa.Jumlah imigran yang juga cukup banyak adalah Kecamatan Silih Nara sebesar 18.286 jiwa. Tabulasi pada Gambar 3 memberikan makna bahwa imigran lebih banyak berkumpul dalam teritorial Kecamatan Bebesen dan Silih Nara.

\section{Analisis Estimasi Migrasi Kabupaten Aceh Tengah}

Estimasi model regresi linear berganda dilakukan dengan unit analisis utama adalah migrasi risen. Migrasi risen merupakan perubahan dan pergerakan penduduk dalam lima tahun terahir (2010-2015) yang masuk dan keluar dari Kabupaten Aceh Tengah. Migrasi risen adalah migrasi berdasarkan tempat tinggal lima tahun yang lalu. Seseorang dikategorikan sebagai migran risen jika provinsi atau kabupaten/kota tempat tinggalnya lima tahun yang lalu berbeda dengan tempat tinggalnya sekarang (saat pencacahan).

Angka migrasi risen masuk di suatu provinsi adalah perbandingan antara jumlah penduduk yang tempat tinggal lima tahun yang lalu berbeda dengan tempat tinggal sekarang, dengan penduduk pertengahan tahun di provinsi tempat tinggal sekarang. Penduduk pertengahan tahun disini adalah penduduk lima tahun ke atas. Pada analisis berikut ini mengklasifikasikan model pada tiga bentuk, yaitu model sosial, ekonomi, dan infrastruktur.

\section{Model Sosial terhadap Pola Migrasi}

Model estimasi migrasi pada model sosial menyertakan variabel sosial beban ketergantungan, kesehatan, dan pendidikan. Model sosial ini menjelaskan hubungan antara variabel beban ketergantungan, pendidikan, dan fasilitas kesehatan terhadap banyak penduduk yang masuk di Kabupaten Aceh Tengah berdasarkan ukuran migrasi risen. Hasil estimasi dirangkum dalam Tabel 1. Model persamaan dari hasil estimasi dengan software E-views 8 dapat dituliskan sebagai berikut:

$$
\begin{aligned}
M R= & 54.387-881 B K-121 \text { Faskes }+ \\
& 19 E d u c+e
\end{aligned}
$$

Hasil estimasi yang dilakukan atas model itu menghasilkan nilai $R$-Squared yang tinggi, dengan makna bahwa model estimasi migrasi risen memiliki keeratan hubungan dengan variabel-variabel sosial sebesar $69 \%$. Hasil ini juga dapat terkonfirmasi dengan nilai $f$-statistik yang signifikan pada taraf kepercayaan (degree of freedom) sebesar $99 \%$.

Tabel 1. Hasil Estimasi Model Sosial Migrasi Penduduk di Kabupaten Aceh Tengah Periode 2010-2015

\begin{tabular}{ccc}
\hline \multirow{2}{*}{ Variabel } & \multicolumn{2}{c}{ Dependent Variable $:$ Migrasi Risen } \\
\cline { 2 - 3 } & Koefisien & t-stat \\
\hline Constant Parameter $(\mathrm{C})$ & 54.387 & $(2,92)^{* * *}$ \\
Beban Ketergantungan $($ BK $)$ & -881 & $(-3,06)^{* * *}$ \\
Fasilitas Kesehatan (Faskes) & -121 & $(0,54)^{*}$ \\
Pendidikan (Educ) & 19 & $(2,9)^{* *}$ \\
\hline $\mathrm{R}^{2}$ & \multicolumn{3}{|}{0,69} \\
F-Stat & \multicolumn{3}{c}{$7,41^{* * * *}$} \\
\hline
\end{tabular}

Keterangan: Angka dalam tanda kurung merupakan t-stat dengan taraf kepercayaan; ${ }^{* * * *}$ Significant pada $\alpha$ $=1 \%(\mathrm{p}<0,01) ;{ }^{* *}$ Significant pada $\alpha=5 \%(\mathrm{p}<0,05) ;$ Significant pada $\alpha=10 \%(\mathrm{p}<0,1)$.

Sumber: Data sekunder (diolah), Tahun 2017. 
Variabel beban ketergantungan $(B K)$ memiliki probability kurang dari $1 \%$ sehingga menolak $\mathrm{H}_{0}$, yang berarti bahwa terdapat pengaruh yang signifikan terhadap jumlah migrasi risen Kabupaten Aceh Tengah pada tingkat kepercayaan 99\%. Tanda negatif pada varibel ini bermakna bahwa apabila beban ketergantungan naik/tumbuh sebesar $1 \%$ maka jumlah migrasi yang akan masuk akan berkurang 881 jiwa, dengan asumsi bahwa faktor-faktor lain di luar model dianggap tetap (ceteris paribus).

Variabel fasilitas kesehatan (Faskes) tampak tidak signifikan dalam mempengaruhi migrasi risen di Kabupaten Aceh Tengah. Setidaknya ini menjadi gambaran bahwa pola migrasi penduduk tidak dipengaruhi oleh banyaknya jumlah fasilitas kesehatan yang dibangun.

Variabel jumlah penduduk yang tidak sekolah $(E d u c)$ memiliki probability kurang dari $5 \%$ sehingga menolak $\mathrm{H}_{0}$, yang berarti bahwa terdapat pengaruh yang signifikan terhadap variabel Migrasi risen yang masuk pada tingkat kepercayaan 95\%. Apabila masyarakat yang tidak mengecam pendidikan naik 1 dari penduduk/jiwa maka migrasi risen yang masuk akan semakin meningkat sebanyak 19 penduduk/jiwa dengan asumsi bahwa faktor-faktor lain di luar model dianggap tetap (ceteris paribus).

Jika dilihat dari kacamata sosial, migrasi yang masuk-keluar di Kabupaten Aceh Tengah sangat dipengaruhi oleh tingkat pendidikan dan angka Beban Ketergantungan $(B K)$. Variabel ini dapat meningkatkan jumlah migrasi risen yang masuk sebanyak 19 penduduk $(E d u c)$ dan mengurangi migrasi masuk 881 penduduk (pengaruh $B K$ ). Gambar 4 merangkum data penduduk yang tidak sekolah dan beban ketergantungan keluarga.

Gambar 4 menggambarkan bahwa kecamatan yang jumlah penduduk yang tidak sekolahnya banyak cenderung memiliki beban ketergantungan yang tinggi. Kecamatan Rusip Antara menjadi daerah dengan angka beban ketergantungan yang tinggi, mencapai $64 \%$ dari total rumah tangga. Penduduk yang tidak sekolah di Kecamatan tersebut juga yang terbanyak, dengan jumah putus sekolah sebesar $12 \%$ dari total penduduk.

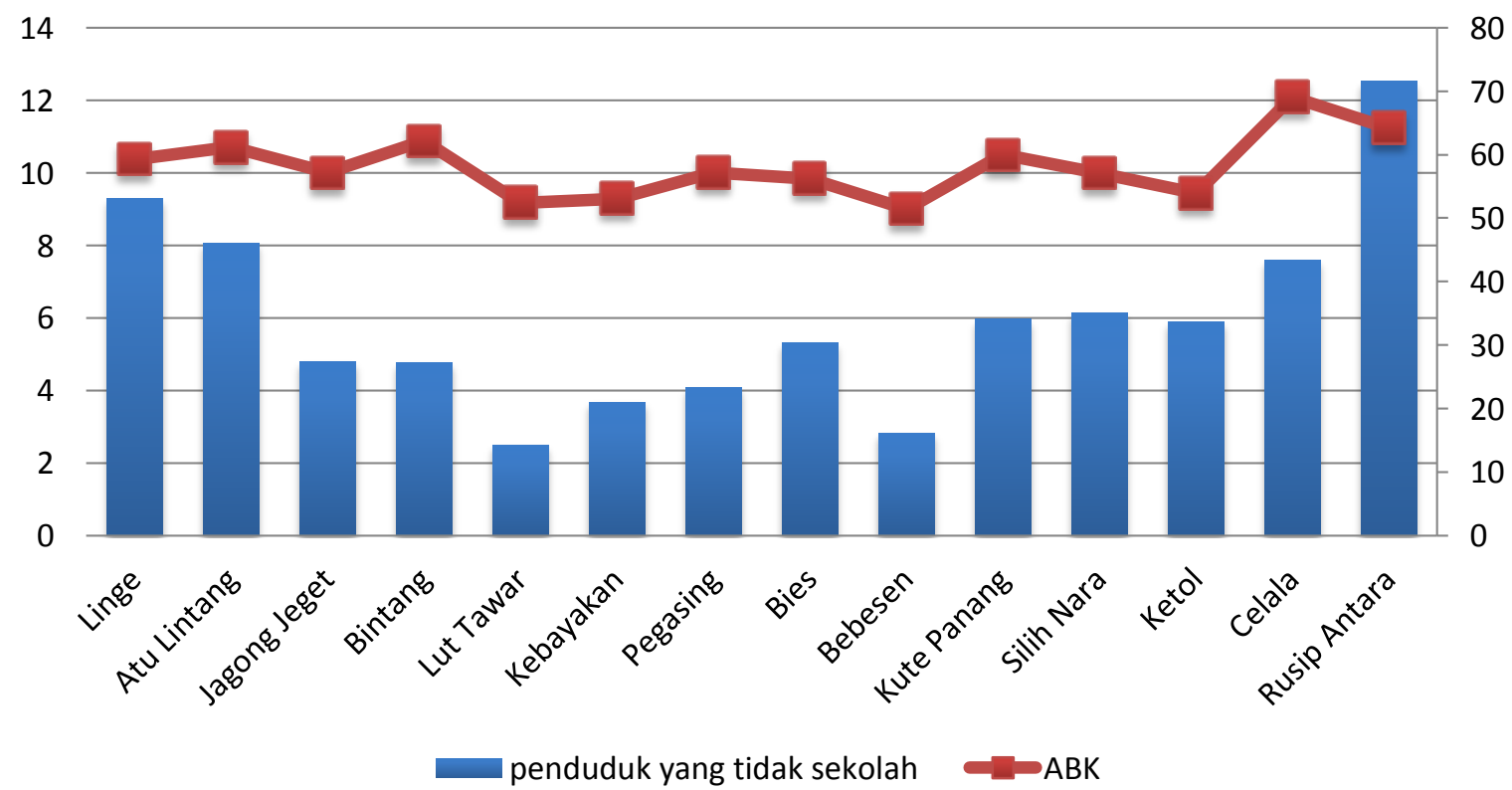

Sumber: Data sekunder (diolah), Tahun 2017.

Gambar 4.Jumlah Penduduk yang Tidak Sekolah dan Beban Ketergantungan Keluarga di 14 Kecamatan Kabupaten Aceh Tengah 
Tabel 2. Hasil Estimasi Model Ekonomi/Ketenagakerjaan Migrasi Penduduk di Kabupaten Aceh Tengah Periode 2010-2015

\begin{tabular}{lcc}
\hline \multirow{2}{*}{ Variabel } & \multicolumn{2}{c}{ Dependent Variable : Migrasi Risen } \\
\cline { 2 - 3 } & Koefisien & t-stat \\
\hline Constant Parameter $(C)$ & 10.220 & $(1,09)$ \\
Tingkat Partisipasi Angkatan Kerja & 1,62 & $(18,76)^{* * *}$ \\
$\quad(T P A K)$ & & $(-3,57)^{* * *}$ \\
Rasio Penduduk Bekerja terhadap & $-1,72$ & $(3,2)^{* * *}$ \\
$\quad$ Total Penduduk $(B)$ & & $(-0,3)$ \\
Kepadatan $(K)$ & 4,62 & \\
Persentase Pajak Bumi dan & $-1,51$ & \\
Bangunan $(P B B)$ & & 0,99 \\
\hline $\mathrm{R}^{2}$ & \multicolumn{3}{c}{$51,9^{* * *}$} \\
\hline F-Stat & & \\
\hline
\end{tabular}

Keterangan: Angka dalam tanda kurung merupakan t-stat dengan taraf kepercayaan; ${ }^{* * *}$ Significant pada $\alpha$ $=1 \%(\mathrm{p}<0,01) ;{ }^{* *}$ Significant pada $\alpha=5 \%(\mathrm{p}<0,05) ;$ Significant $\mathrm{pada} \alpha=10 \%(\mathrm{p}<0,1)$.

Sumber: Data sekunder (diolah), Tahun 2017.

Jika dilihat hubungan yang berbeda, tafsiran yang bisa dijelaskan yaitu bahwa peningkatan jumlah migrasi masuk karena banyaknya penduduk yang tidak sekolah pada suatu kecamatan. Artinya, pergerakan migrasi penduduk akan semakin tertuju pada daerah yang tertinggal dalam segi pendidikannya. Jika hal ini terjadi, maka gejala migrasi yang masuk diikuti oleh kesenjangan pendidikan antara pendatang dengan penduduk setempat.

Angka beban ketergantungan yang turun akan meningkatkan migrasi risen penduduk di Kabupaten Aceh Tengah. Gejala ini memperlihatkan bahwa seseorang mampu lepas dari ketergantungan, maka akan diikuti dengan penambahan jumlah migrasi yang keluar di kecamatan tersebut. Ada suatu keputusan secara sosial bagi masyarakat untuk berpindah tempat dari daerah asalnya saat sudah mampu lepas dari ketergantungan keluarga.

\section{Model Ekonomi/Ketenagakerjaan atas Pola Migrasi}

Model estimasi migrasi menyertakan variabel ketenagakerjaan.Model ekonomi ini menjelaskan hubungan antara variabel partisipasi angkatan kerja, rasio penduduk bekerja, kepadatan, dan Pajak Bumi Bangunan terhadap banyak penduduk yang masuk di dalam Kabupaten Aceh Tengah berdasarkan ukuran migrasi risen. Hasil estimasi dirangkum dalam Tabel 2.

Model persamaan dari hasil estimasi yang diperoleh dengan software E-views 8 dapat dituliskan sebagai berikut:

$$
\begin{aligned}
M R= & 10.220+1,62 T P A K-1,72 B+4,62 K \\
& -1,51 P B B+e
\end{aligned}
$$

Hasil estimasi yang dilakukan menunjukkan nilai $R$-Squared yang sangat tinggi, dengan makna bahwa model estimasi migrasi risen memiliki keeratan hubungan dengan variabel-variabel ekonomi sebesar 99\%. Hasil ini juga dapat terkonfirmasi dengan nilai $f$-stat yang signifikan pada taraf kepercayaan (degree of freedom) sebesar $99 \%$.

Variabel tingkat pasrtisipasi angkatan kerja (TPAK) memiliki probability kurang dari $1 \%$ sehingga menolak $\mathrm{H}_{0}$, yang berarti bahwa terdapat pengaruh yang signifikan terhadap jumlah migrasi risen Kabupaten Aceh Tengah pada tingkat kepercayaan 99\%. Tanda positif pada variabel ini bermakna bahwa apabila tingkat partisipasi angkatan kerja naik/tumbuh sebesar $1 \%$ maka jumlah migrasi yang akan masuk akan meningkat sebesar $1,62 \%$, dengan asumsi bahwa faktor- 
faktor lain di luar model dianggap tetap (ceteris paribus).

Variabel rasio penduduk bekerja atas total penduduk (B) memiliki probability kurang dari $1 \%$ sehingga menolak $\mathrm{H}_{0}$, yang berarti bahwa terdapat pengaruh yang signifikan antara penambahan rasio penduduk berkarja terhadap angka migrasi risen pada tingkat kepercayaan 99\%. Berbeda dengan koefisien pada partisipasi angkatan kerja, jumlah rasio penduduk yang bekerja memiliki pengaruh positif terhadap migrasi risen. Hal tersebut bermakna bahwa kenaikan jumlah penduduk yang bekerja akan mengurangi migrasi yang masuk ke dalam Kabupaten Aceh tengah sebesar $1,72 \%$ dengan asumsi variabel lain di luar model tetap.

Variabel kepadatan penduduk $(K)$ juga signifika pada probability tingkat kepercayaan 90\%.Kepadatan penduduk menjadi sebab terjadinya migrasi risen, dimana jika terjadi kenaikan kepadatan penduduk $1 \%$ akan diikuti dengan peningkatan jumlah migrasi risen sebesar $4,62 \%$, dengan asumsi bahwa faktor-faktor lain di luar model dianggap tetap (ceteris paribus).

Pada variabel pajak bumi bangunan $(P B B)$, tingkat signifikansi dari variabel di bawah dari probabilitas (90\%, 95\%, 99\%). Hal ini berarti tidak ada pengaruh antara besaran pajak bumi bangunan yang diperoleh kecamatan atas pergerakan migrasi risen yang masuk ke Kabupaten Aceh Tengah.

Dari aspek ekonomi, pola migrasi bergerak berdasarkan faktor ketenagakerjaan. Dalam analisis yang dilakukan pada model ekonomi, tingkap partisipasi angkatan kerja yang meningkat akan meningkatkan pola migrasi penduduk di Kabupaten Aceh Tengah. Namun tingkat partisipasi ini tidak diikuti dengan peningkatan jumlah penduduk yang bekerja, karena keputusan migrasi justru bertolak belakang dengan jumlah penduduk yang bekerja tetap.

Gejala yang terjadi adalah penduduk imigran cenderung memiliki tingkat partisipasi kerja yang tinggi dan berpindah ke suatu tempat. Namun kecenderungan yang terjadi penduduk imigran tidak memperoleh pekerjaan tetap. Hal ini mengakibatkan adanya ketimpangan penduduk pendatang dan penduduk tetap. Pada Gambar 5 ditampilkan data terkait kondisi ketenagakerjaan di Kabupaten Aceh Tengah. Dari data tersebut tampak bahwa tingkat pengangguran tertinggi terajadi di Kematan Bebesen dengan jumlah penduduk yang menganggur sebanyak 25.641 jiwa. Total pengangguran di Kabupaten Aceh Tengah sebanyak 111.861 jiwa. Jumlah ini dirasiokan sebanyak 56\% dari total penduduk.

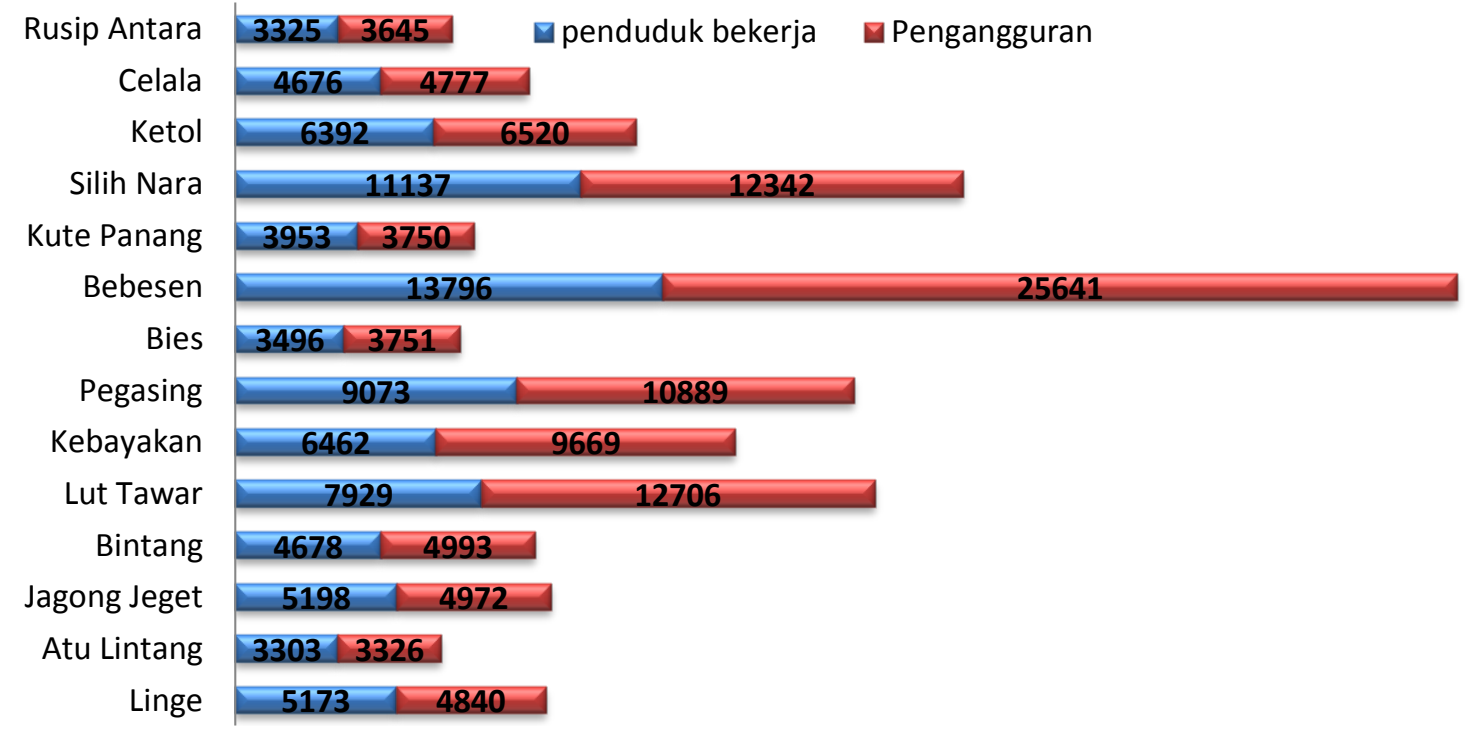

Sumber: Data sekunder (diolah), Tahun 2017.

Gambar 5. Jumlah Penduduk Bekerja dan Pengangguran di 14 Kecamatan Kabupaten Aceh Tengah 
Tabel3. Hasil Estimasi Model Infrastruktur Migrasi Penduduk di Kabupaten Aceh Tengah Periode 2010-2015

\begin{tabular}{lcc}
\hline \multirow{2}{*}{ Variabel } & \multicolumn{2}{c}{ Dependent Variable $:$ Migrasi Risen } \\
\cline { 2 - 3 } & Koefisien & t-stat \\
\hline Constant Parameter $(C)$ & -4.981 & $(1,09)^{* * *}$ \\
Listrik $(L)$ & 57,84 & $(2,61)^{* * *}$ \\
Perumahan $(P)$ & 3,72 & $(53,1)^{* * *}$ \\
Komunikasi $(K)$ & $-8,13$ & $(-0,79)$ \\
\hline \multicolumn{1}{c}{ F-Stat } & \multicolumn{3}{c}{0,99} \\
$\mathrm{R}^{2}$ & \multicolumn{3}{c}{$1.410^{* * *}$} \\
\hline
\end{tabular}

Keterangan: Angka dalam tanda kurung merupakan t-stat dengan taraf kepercayaan; ${ }^{* * *}$ Significant pada $\alpha$ $=1 \%(\mathrm{p}<0,01) ;{ }^{* *}$ Significant pada $\alpha=5 \%(\mathrm{p}<0,05) ;{ }^{*}$ Significant pada $\alpha=10 \%(\mathrm{p}<0,1)$.

Sumber: Data sekunder (diolah), Tahun 2017.

\section{Model Infrastruktur dalam Pola Migrasi}

Model estimasi migrasi pada model ekonomi menyertakan variabel infrastruktur seperti perumahan, listrik, dan akses komunikasi. Model ekonomi ini menjelaskan hubungan antara variabel partisipasi angkatan kerja, rasio penduduk bekerja, kepadatan, dan Pajak Bumi Bangunan terhadap banyak penduduk yang masuk di Kabupaten Aceh Tengah berdasarkan ukuran migrasi risen. Hasil estimasi dirangkum dalam Tabel 3.

Model persamaan dari hasil estimasi yang diperoleh dengan software E-views 8 dapat dituliskan sebagai berikut:

$$
M R=-4.981+57,84 L+3,72 P-8,13 K+e
$$

Hasil estimasi diperoleh menyatakan nilai $R$-Squared yang sangat tinggi, dengan makna bahwa model estimasi migrasi risen memiliki keeratan hubungan dengan varibelvariabel ekonomi sebesar 99\%. Hasil ini juga dapat terkonfirmasi dengan nilai $f$-stat yang signifikan pada taraf kepercayaan (degree of freedom) sebesar $99 \%$.

Variabel sumber penerangan listrik $(L)$ memiliki probability kurang dari 5\% sehingga menolak $\mathrm{H}_{0}$, yang berarti bahwa terdapat pengaruh yang signifikan terhadap jumlah migrasi risen Kabupaten Aceh Tengah pada tingkat kepercayaan 95\%. Interpretasinya adalah apabila akses penerangan listik di Kabupaten Aceh Tengah meningkat 1 persen maka jumlah migrasi yang akan masuk akan meningkat sebesar 57,84\%, dengan asumsi bahwa faktor-faktor lain di luar model dianggap tetap (ceteris paribus).

Variabel jumlah penduduk yang memiliki rumah $(P)$ memiliki probability kurang dari $1 \%$ sehingga menolak $\mathrm{H}_{0}$, yang berarti bahwa terdapat pengaruh yang signifikan antara jumlah penduduk yang memiliki rumah terhadap angka migrasi risen pada tingkat kepercayaan 99\%. Hal tersebut bermakna bahwa jika penduduk yang memiliki rumah meningkat $1 \%$, maka migrasi risen yang masuk meningkat sebesar 3,72\% dengan asumsi variabel lain di luar model tetap.

Variabel akses komunikasi penduduk $(K)$ tampak tidak signifikan terhadap jumlah migrasi masuk. Artinya, variabel ini tidak berpengaruh terhadap jumlah migrasi.

Jika dilihat dari segi jumlah penduduk yang memiliki akses perumahan, pola migrasi menunjukkan hubungan yang signifikan. Penambahan jumlah penduduk yang memiliki rumah akan meningkatkan migrasi yang masuk ke Kabupaten Aceh Tengah. Gejala ini menunjukkan bahwa keputusan migrasi masuk ditengarai karena alasan mencari tempat tinggal untuk kebutuhan hidup layak. Kondisi perumahan berdasarkan data yang dikumpulkan pada tingkat kecamatan ditampilkan dalam Gambar 6. 


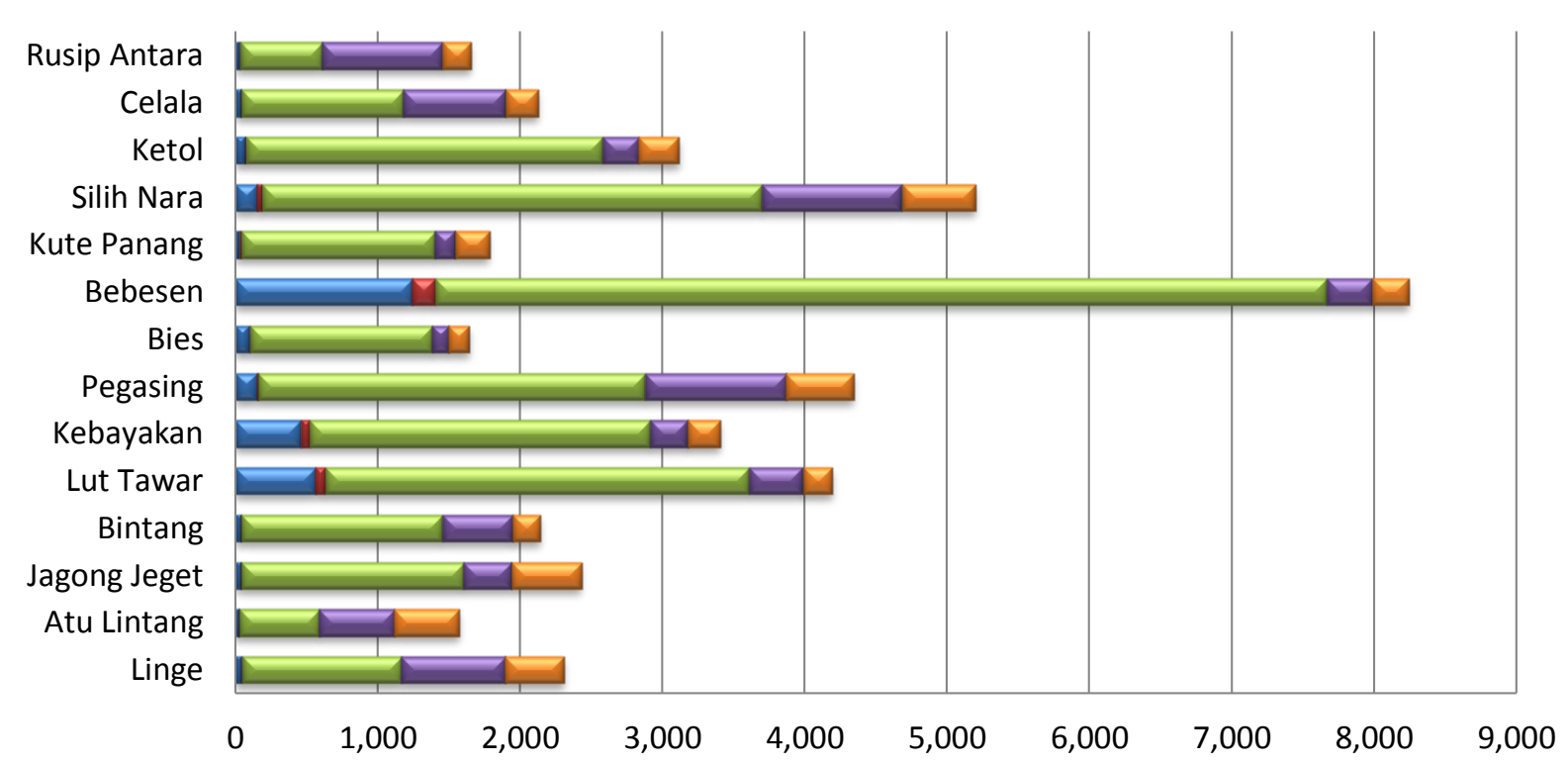

$\square$ Keramik/Marmer/Granit $\square$ Ubin/Tegel/Teraso $\square$ Semen/Bata Merah $\square$ Kayu/Papan $\square$ Bambu $\square$ Tanah

Sumber: Data sekunder (diolah), Tahun 2017.

\section{Gambar 6. Kondisi Perumahan Kabupaten Aceh Tengah berdasarkan Jenis Lantai}

\begin{abstract}
Penduduk Kabupaten Aceh Tengah secara umum, memiliki rumah dengan bangunan dasar dan lantai semen/batu bata. Hal ini menunjukkan kondisi perumahan yang masih minim secara fasilitas. Sebanyak ratarata 506 penduduk masih tinggal dengan kondisi perumahan kayu dan papan. Kecamatan Bies menjadi daerah dengan akses perumahan yang paling sedikir, yaitu hanya sejumlah 1.642 rumah tangga yang memiliki perumahan dari berbagai kondisi lantai.

Variabel infrastrukut yang dinilai mempengaruhi migrasi penduduk adalah sumber penerangan. Keputusan migrasi penduduk dipengaruhi secara signifikan oleh keadaan listrik dan sumber penerangan. Jika akses listrik di Kecamatan meningkat $1 \%$, maka mendorong migrasi yang masuk sebesar $57,84 \%$. Variabel ini tercatat sebagai faktor paling besar yang mempengaruhi pola pergerakan migrasi. Jika dikalkukasikan tidak kurang sebanyak $57,84 \%$ penduduk yang bermigrasi dikarenakan alasan akses terhadap sumber penerangan listik di kecamatankecamatan di dalam wilayah Kabupaten Aceh Tengah.
\end{abstract}

\section{KESIMPULAN}

Berdasarkan hasil analisis pola migrasi penduduk di Kabupaten Aceh Tengah dapat disimpulkan: (1) pola migrasi penduduk yang terjadi di Kabupaten Aceh Tengah tergolong tinggi dengan jumlah penduduk imigran ratarata $85 \%$ dari total penduduk; dimana keputusan bermigrasi dipengaruhi oleh faktor sosial, ekonomi, dan infrastruktur; (2) secara sosial, migrasi penduduk di Kabupaten Aceh Tengah dipengaruhi oleh faktor pendidikan, angka beban ketergantungan, dan fasilitas kesehatan; (3) secara aspek ekonomi, faktor ketenagakerjaan berpengaruh signifikan di dalam pergerakan migrasi di Kabupaten Aceh Tengah; dimana variabel-variabel ketenagakerjaan yang berpengaruh terhadap migrasi risen adalah tingkat partisipasi angkatan kerja, jumlah penduduk yang bekerja, dan kepadatan penduduk; serta, (4) secara aspek infrastruktur, kondisi perumahan dan akses penerangan listrik menjadi faktor utama yang mempengaruhi keputusan migrasi penduduk di Kabupaten Aceh Tengah.

Berdasarkan beberapa kesimpulan yang dinyatakan, direkomendasikan beberapa hal. Pertama, perlu adanya tinjauan secara 
struktural ekonomi berkenaan dengan alasan penduduk bermigrasi di Kabupaten Aceh Tengah dalam lingkup yang lebih mikro, karena penelitian ini hanya difokuskan pada sisi aspek ekonomi ketenagakerjaan. Kedua, hendaknya dalam proses pengambilan kebijakan, Pemerintah Kabupaten Aceh Tengah sebaiknya memberi perhatian yang besar terhadap penduduk imigran yang masuk ke Kabupaten Aceh Tengah. Ketiga, perlu perbaikan infrastruktur agar migrasi yang masuk mampu menampung penduduk dengan kondisi yang layak secara perumahan dan akses listrik. Terakhir, penelitian selanjutnya perlu dilakukan dalam telaah lebih mendalam dari sisi sosio-cultural keputusan bermigrasi di Kabupaten Aceh Tengah.

\section{DAFTAR PUSTAKA}

Borjas, G.J. 2000. Economics of Migration. International Encyclopedia of Social and Behavioral Sciences. Section No. 3.4, Article No. 38. USA: Harvard University.

BPS. 2015. Migrasi Internal Penduduk Indonesia Hasil Sensus Penduduk 2010. http://sp2010.bps.go.id.

Emalisa. 2003. Pola dan Arus Migrasi di Indonesia. Sumatera Utara: Jurusan Sosial Ekonomi Pertanian Fakultas Pertanian Universitas Sumatera Utara.

Etzo, I. 2008. Internal Migration: A Review of the Literature. University of Cagliari. May 2008. http://mpra.ub.uni muenchen.de/8783/. MPRA Paper No. 8783. Diunduh tanggal 15 Agustus 2017.
Faturochman. 2002. Nasib Migran dan Dominasi Konsep Migrasi. Yogyakarta: Gajah Mada University.

Jones, T.A. 2009. Migration Theory in the Domestic Context, North-South Labor Movement in Brazil. Human Architecture: Journal of the Sociology of Self-Knowledge. Vol. 7, No. 4, hal.5-14.

Lee, E.S. 1966. A Theory of Migration. Demography. Vol. 3, No. 1, hal.4757.

Munir, R. 2011. Migrasi. Dasar-dasar Demografi. Ed. Sri Moertiningsih Adioetomo \& Omas Bulan Samosir. Depok: Salemba Empat dan Lembaga Demografi Fakultas Ekonomi Universitas Indonesia, hal. 133-153.

Skeldon, R. 1997. Migration and Development: A Global Perspective. Essex: Longman.

Tjiptoherijanto, P. 2000. Mobilitas Penduduk dan Pembangunan Ekonomi. Makalah. Simposium Dua Hari Kantor Menteri Negara Transmigrasi dan Kependudukan/BAKMP, 25-26 Mei. Jakarta.

Todaro, M.P. 1980. Internal Migration in Developing Countries: A Survey Population and Economic Change in Developing Countries. USA: University of Chicago Press.

Wajdi, M.N. 2010. Migrasi Antar Pulau Di Indonesia: Analisis Model Skedul Migrasi dan Model Gravitasi Hybrida. Tesis. Depok: Program Studi Kajian Kependudukan dan Ketenagakerjaan Program Pascasarjana Universitas Indonesia. 